\title{
Effect of Indoor Pesticide on Neurobehavior Test Battery among Basic School Children in a Rural Area, Menoufia Governorate, Egypt
}

Taghreed M Farahat, Hala M Shaheen, Fatma A EL Esrigy, Dina M Elmatbaagy

Family Medicine Department, Faculty of Medicine, Menofoufia University

\begin{abstract}
:
Background: Children's exposure to neurotoxic compounds as pesticide poses a major problem for child health.Objective: To assess the prevalence of indoor pesticide use and the effect of its use on the neurobehavior test battery of Basic School Children aged 9-13 years. Methods:A cross-sectional study was conducted on 260 school age children (9-13) years old in Munshaat Sultan primary and preparatory schools during the period of data collection. All studied children were evaluated through history taking, general and neurological examination. Five neurobehavioral test batteries measure cognitive domain were used to assess the neurobehavioral development. Results: Most of the study participants reported indoor pesticide use (89\%). It was found that indoor pesticide use was significantly higher among participant whose mothers didn't work and having a secondary education $(62 \%, 57 \%)$ respectively $(\mathrm{p}$ value $<0.05$ ). The studied participants with indoor pesticide use exhibited highly statistically significantly lower performance in neurobehavioral test batteries than non-user. Moreover, there was a statistically significant positive correlation between the number of pesticides' bottles used and neurobehavioral test (Trail making) ( $\mathrm{p}$ value $<0.001)$ while this correlation was negative in Digital span, Digital symbols, Similarity test and PASAT (p-value <0.05). Conclusion: Children exposure to the indoor pesticide is a prevalent problem which had a significant effect on their neurobehaviour. So we recommend to increase the community awareness regarding indoor pesticide use and exposure.
\end{abstract}

Key Words: Batteries, children, neurobehavior, indoor pesticide.

Introduction: Pesticides are used widely to control weeds and insect infestation in agricultural fields and various pests and disease carriers (e.g., mosquitoes, flies, ticks, rats, and mice) in houses, malls, offices, and streets. ${ }^{(1)}$ However, unintended exposure to pesticides can be considered extremely hazardous to humans and other living organisms as they are designed to be poisonous. $^{(2)}$

Children have been identified as particularly vulnerable to uptake of pesticides from their environment due to frequent handto-mouth behavior, mouthing of nonfood items, increased contact with soil, floors, and carpets where spray residues settle, and higher concentrations of pesticide residues close to the floor in their breathing zone. ${ }^{(3)}$ Even very low levels of pesticide exposure may have adverse health effects at early development. ${ }^{(4)}$ Their physical makeup, behavior, and physiology of children make them more susceptible to pesticides hazards than adults. ${ }^{(5)}$

The hazards range from short-term (e.g., skin and eye irritation, headaches, acute neurologic toxicity, and nausea) to chronic impacts (e.g., cancer, chronic neuron developmental impairment, asthma, and diabetes, reproductive dysfunction, and possibly dysfunction of the immune and endocrine system). ${ }^{(6)}$ Exposure to pesticides has been consistently linked to

*Corresponding author: E-mail: Dinamostafa189@gmail.com 
neurobehavioral deficits in children and adolescents as reported a dose-effect relationship between increased years of exposure to pesticides and cognitive deficits in adolescent Egyptian agricultural adolescents. ${ }^{(7)}$ Numerous cross-sectional and longitudinal cohort studies have provided evidence of associations between neuro-behavioral performance impairments and postnatal childhood and adolescent pesticide exposure. ${ }^{(8)}$

The current study is aiming to assess the prevalence of indoor pesticide use and the effect of its use on the neurobehavior test battery of basic school children aged 9-13 years in a Rural Area, Menoufia Governorate, Egypt.

Methods:The study was approved by the Research Ethics Committee of Menoufia University, and written informed consent was signed by one of the parents.

This study was a cross-sectional study carried out in Munshaat Sultan village, Menouf district during the period from the 1st of July 2016 until the end of April 2018.. Menouf district was selected by multistage stratified random sampling from districts affiliated to Menoufia governorate (13 districts), then Munshaat Sultan village was selected randomly from villages affliated to Menouf district.

The target population was basic school children aged (9-13) years old in Munshaat Sultan primary and preparatory schools (1 primary, 1 preparatory) (this age group was selected to be able to deal with the battery tests).

The sample size was calculated using the online raosoft program, based on the prevalence of indoor pesticide use from previous literatures which was $75 \% .^{(9)}$ Considering the confidence interval $95 \%$ and the power of the study $80 \%$, the calculated sample was 240 children and increased to 260 children to avoid the dropout which was proportionally allocated according to the total number of children in each school (145 Children from primary school and 115 children from preparatory school). A class from each grade was selected, each class includes (50-60) children.

Pilot study was done, to measure the feasibility of study setting, content and validity of the used tools, on a convenient sample of ten accepted subjects and were excluded from the study.

Exclusion Criteria:Children in first, second, third primary grade and third preparatory, Children with any chronic medical disorders as diabetes mellitus, hypertension, or any neurological disorder e.g. epilepsy, chronic medication use, Uncooperative children or Parents were excluded from the study.

Each child of the study group was subjected to history taking, including personal data such as age, sex, father and mother education and occupation. Social workers 
undertook home visits to get the parents' approval for participation in the study through a written consent and collect the data of the questionnaire after their training to avoid interpersonal bias.

The questionnaire consisted of sociodemographic data according to Fahmy et al., $2015^{(10)}$, data about the presence of indoor insects, rats, the use of pesticide, pattern of applying and number of bottles used per month. This questionnaire classified the studied group into user and non user according to pesticide use inside houses. The neurobehavioral assessment was performed by using Five neurobehavioral validated and reliable test batteries (the Arabic version) measuring cognitive domain which were used in previous studies in Menoufia, Egypt. ${ }^{(7,11,13)}$

Similarities Test, Digit Span Test, Digit Symbol Test, Trail Making and Paired Auditory Serial Addition were selected. Better performance is evaluated by higher scores obtained on tests of Similarities Test, Digit Span Test, Digit Symbol Test and Paired Auditory Serial Addition Test by contrast lower latencies or time to complete Trail Making Test part A. ${ }^{(11)}$ Neurobehavioral battery test were performed by the researcher after training.

Statistical analysis:Data were collected, tabulated, statistically analyzed using an IBM personal computer with Statistical Package for Social Science (SPSS) version 23. Quantitative data were presented as mean, standard deviation (SD) and range and analyzed using Student t-test. Qualitative data were presented in numbers and percentages and analyzed using a Chi-squared test. (P-value) less than 0.05 was considered statistically significant.

Results: The prevalence of indoor pesticide use among the studied children was $88.9 \%$ (figure 1).There was a statistically significant relationship between indoor pesticide use, Mother's work and education ( $\mathrm{p}$-value $<0.05$ ), as about two third of the participants with indoor pesticides, use didn't work $(62 \%)$ and with mothers having a secondary education $(57 \%)$ (table 1).

Most of the studied participants with indoor pesticide use reported that they did not reuse the empty bottles of pesticide (85\%), close windows during pesticide use $(71.2 \%)$ and store the pesticide bottles at a specific place $(69.6 \%)$ (table 2). The studied participants with indoor pesticide use exhibited highly statistically significantly lower performance in Similarity test, Digital symbols, Digital span, Trail making (sec), PASAT (p-value <0.001) (table 3). There was a positive significant correlation between the number of pesticides' bottles used and neurobehavioral test (Trail making) while this correlation was negative in Digital span, Digital symbols, Similarity test and PASAT (table 4). 
Discussion: Daily, chronic low level of exposures to pesticides are more common today among children than acute pesticide poisoning. ${ }^{(12)}$ The present study revealed that that the prevalence of indoor pesticide use among the studied participants was $89 \%$. This is in concordance with the result of Farahat et al study who found that $80.5 \%$ of the studied Egyptian Agricultural Families use pesticide frequently in homes. ${ }^{(13)}$

Also, a study of Minnesota households with children found that pesticide products were stored in $97 \%$ of the households investigated, and as many as $88 \%$ of the households reportedly had used pesticides within the past year. ${ }^{(14)}$ Also, the U.S. Environmental Protection Agency (EPA) has estimated that nearly $75 \%$ of American households use pesticides. ${ }^{(9)}$

As regards socio-demographic characteristics of the studied participants, the present study denoted that the use of indoor pesticide was statistically higher among participant with not working and with mothers having secondary education. This in agreement with Berkowitz et al., who showed that the higher proportions of pesticide exposure were significantly seen among the lowest educational females. ${ }^{(15)}$ On the other hand, this study disagrees with Lizardi who reported that Father's years of education was the only characteristic that was significantly different between the original Exposed and Non- exposed as fathers in the Exposed group had significantly less number of years of education than the fathers in the Non-exposed group. ${ }^{(\mathbf{1 6})}$ This difference may be attributed to the different culture and demographic data

Also against Dawson et al., who found that there was no difference between exposed and non exposed children in age, gender, years of education of child, mother, and father. ${ }^{(17)}$

The current study showed that most of the studied participants with indoor pesticide use reported that they did not reuse the empty bottles of pesticide, close windows during pesticide use and store the pesticide bottles at a specific place. Farahat et al., reported that $47.5 \%$ did not close windows during application of pesticides and only $12.5 \%$ reuse the empty bottles, and $77.5 \%$ of women stored the empty containers in any place either inside or outside the home. ${ }^{(18)}$ Also, Dawson et al., showed that only $10 \%$ reported that they reused their empty pesticide Containers. ${ }^{(8)}$

The current study showed that the neurobehavioral Performance is statistically lower among participants with indoor pesticide use.These result in agreement with effects (Farahat et al., 2003 and Abdel Rasoul et al., 2008) studies in adult pesticide workers and adolescent (9-15 y) pesticide applicators respectively in the same governorate in Egypt. ${ }^{(7,11)}$ Also Rohlman et al., who showed that adolescents working in agricultural had a 
poorer performance with Digit Span, Digit Symbol, and Serial Digit Learning tests. ${ }^{(19)}$

More-ever, Eckerman et al., denoted that increasing pesticide exposure was found to be associated with impairments in Tapping, Digit Span, and Selective Attention. ${ }^{(20)}$ In contrast, lizard et al., found that Higher OP pesticide metabolites in urine were correlated with higher performance on some tests of the Wisconsin Card Sorting tests. ${ }^{(17)}$ Also, Fiedler et al revealed no significant adverse neurobehavioral effects were observed between participant groups during either the high or low pesticide use season. ${ }^{(21)}$ The variation between studies may be attributed to the differences in study design and population, exposure measurement, and neurobehavioral tests.

The present study denotes that the higher the number of pesticides' bottles used the lower performance in trail making test, Digital span, Digital symbols, Similarity test and PASAT.This agrees with Dawson et al who showed that several neurobehavioral outcomes were significantly poorer for the high exposed pesticide handlers compared to the low exposed referent farmers in the univariate analysis, The higher exposure assessed by the duration of pesticide use, the frequency of use. $^{(8)}$

Conclusion: Children exposed to indoor pesticide are a prevalent problem which had a significant effect on their neuro-behavior, so it is recommended to increase the community awareness regarding indoor pesticide use and exposure.

Study limitation:Difficulty to follow the study steps. Neurobehavioral assessment was difficult because many tests are time consuming and need long time to explain how to perform these tests. Also, laboratory investigations were difficult due to high cost

Conflict of interest: No conflict of interest.

\section{References:}

1.Gilden RC, Huffling K, Sattler B. Pesticides and health risks. J. Obstet. Gynecol. Neonatal. Nurs. 2010; 39 (1): 103-110.

2.Sarwar M. The dangers of pesticides associated with public health and preventing of the risks. Int. J. Bioinfor. Biomed. Eng.2015; 1 (2): 130-136.

3.Roberts JR, Karr CJ. Pesticide exposure in children. Pediatrics. 2012 Dec 1;130(6):e1765-1788.

4.Damalas CA, Eleftherohorinos G.E, Pesticide exposure, safety issues, and risk assessment indicators. Int. J. Environ. Res. Public Health.2011; 8 (5): 1402-1419.

5.Mascarelli A. Growing up with pesticides. Science. 2013;341 (6074): 740-741.

6.Alleva R, Manzella N, Gaetani S, Bacchetti $\mathrm{T}$, Bracci M, Ciarapica $\mathrm{V}$, et al. Mechanism underlying the effect of long-term exposure to low dose of pesticides on DNA integrity. 
Environmental toxicology. 2018 Apr;33(4) : 476-487.

7.Abdel Rasoul GM, Salem ME, Mechael AA, Hendy OM, Rohlman DS, Ismail AA. Effects of occupational pesticide exposure on children applying pesticides. Neurotoxicology. 2008 Sep 1; 29(5):833838.

8.Butler-Dawson J, Kuye R, Sanyang E, Rohlman DS, Thorne PS. Neurobehavioral effects associated with low-level exposure to pesticides in The Gambia. Pesticide exposure, risk factors, and neurobehavioral performance among vulnerable populations. $2015 \mathrm{Dec}$;5: 96-119.

9.Liu J, Schelar E. Pesticide exposure and child neurodevelopment: summary and implications. Workplace health \& safety. 2012 May;60(5):235-242.

10.Fahmy SI, Nofal LM, Shehata SF, El Kady HM, Ibrahim HK. Updating indicators for scaling the socioeconomic level of families for health research. Journal of the Egyptian Public Health Association. 2015 Mar 1;90(1):1-7.

11.Farahat TM, Abdelrasoul GM, Amr MM, Shebl MM, Farahat FM, Anger WK. Neurobehavioural effects among workers occupationally exposed to organophosphorous pesticides. Occupational and environmental medicine. 2003 Apr 1; 60(4):279-286.

Egyptian Family Medicine Journal (EFMJ)
12.Marks AR, Harley K, Bradman A, Kogut $\mathrm{K}$, Barr DB, Johnson C, et al. Organophosphate pesticide exposure and attention in young Mexican-American children: the CHAMACOS study. Environmental health perspectives. 2010 Dec; 118(12):1768-1774.

13.Farahat TM, Farahat FM, Michael AA. Behavioral-Based Educational Intervention Directed toward Egyptian Agricultural Families to Protect Children from Pesticide Exposure. International quarterly of community health education. $2008 \mathrm{Jul}$; 28(2):97-108.

14.Adgate JL, Kukowski A, Stroebel C, Shubat PJ, Morrell S, Quackenboss JJ, Whitmore RW, Sexton K. Pesticide storage and use patterns in Minnesota households with children. Journal of Exposure Science and Environmental Epidemiology. 2000 Apr ;10(2):159-167.

15.Berkowitz GS, Obel J, Deych E, Lapinski R, Godbold J, Liu Z, Landrigan PJ, Wolff MS. Exposure to indoor pesticides during pregnancy in a multiethnic, urban cohort. Environmental Health Perspectives . 2003 Jan; 111(1):79-84.

16.Sánchez Lizardi P, O'rourke MK, Morris RJ. The effects of organophosphate pesticide exposure on Hispanic children's cognitive and behavioral functioning. Journal of pediatric psychology. 2007 Jun 14;33(1):91-101. 
17.Butler-Dawson J, Galvin K, Thorne PS, Rohlman DS. Organophosphorus pesticide exposure and neurobehavioral performance in Latino children living in an orchard community. Neurotoxicology. 2016 Mar 1;53:165-172.

18. Farahat TM, Shaheen HM, Sanad ZF, Farag NA. Knowledge, attitudes, and practices of organophosphorus pesticide exposure among women affiliated to the Manshat Sultan Family Health Center (rural area) in Menoufia governorate: an intervention study. Menoufia medical journal. 2016; 29 (1): 115-120.

19.Rohlman DS, Bailey SR, Anger WK, McCauley L. Assessment of neurobehavioral function with computerized tests in a population of Hispanic adolescents working in agriculture. Environmental Research. 2001 Jan 1;85(1):14-24.

20.Eckerman DA, Gimenes LS, De Souza RC, Galvão PR, Sarcinelli P, Chrisman JR. Age related effects of pesticide exposure on neurobehavioral performance of adolescent farm workers in Brazil. Neurotoxicology and teratology. 2007 Jan 1;29(1):164-175.

21.Fiedler N, Rohitrattana J, Siriwong W, Suttiwan P, Strickland PO, Ryan PB, Rohlman DS, Panuwet P, Barr DB, Robson MG. Neurobehavioral effects of exposure to organophosphates and pyrethroid pesticides among Thai children. Neurotoxicology. 2015 May 1;48:90-99. 
Farahat et al: Indoor pesticide and children

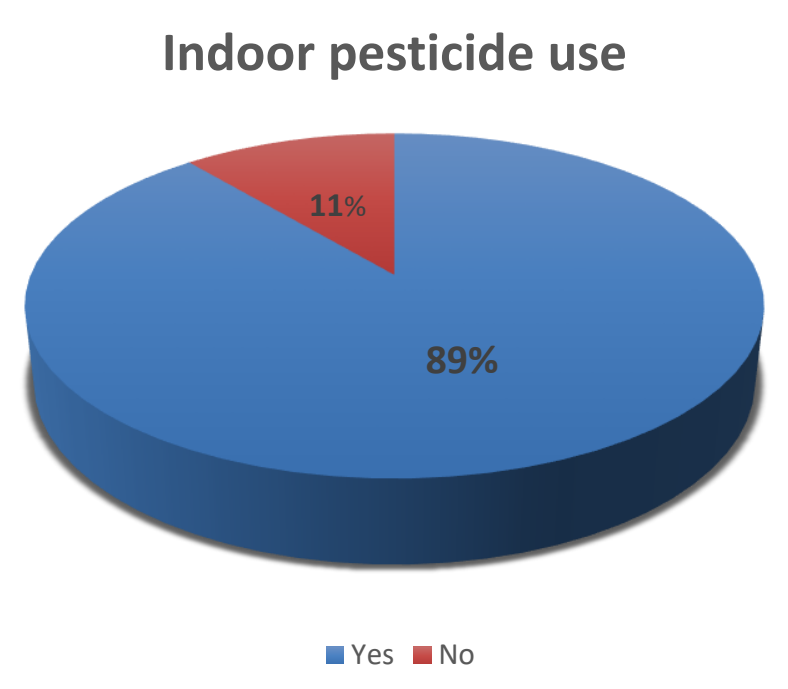

Fig (1): Frequency of indoor pesticide use among the studied participants. 
Farahat et al: Indoor pesticide and children

Table (1): Relationship between indoor pesticide use and sociodemographic characteristics of the studied participants

\begin{tabular}{|c|c|c|c|c|c|c|}
\hline \multirow{3}{*}{ Parameter } & \multicolumn{4}{|c|}{ Indoor pesticide use } & \multirow{3}{*}{$\mathbf{X}^{2}$} & \multirow{3}{*}{$P$ value } \\
\hline & \multicolumn{2}{|l|}{ User } & \multicolumn{2}{|c|}{ Non user } & & \\
\hline & $\mathbf{n}(\mathbf{2 3 1})$ & $\%$ & $\mathbf{n}(29)$ & $\%$ & & \\
\hline $\begin{array}{l}\text { Mother work } \\
\text { - Not Working } \\
\text { - Working }\end{array}$ & $\begin{array}{l}144 \\
87\end{array}$ & $\begin{array}{l}62.3 \\
37.7\end{array}$ & $\begin{array}{l}12 \\
17\end{array}$ & $\begin{array}{l}41.4 \\
58.6\end{array}$ & 4.7 & $\mathbf{0 . 0 3}$ \\
\hline $\begin{array}{l}\text { Father work } \\
\text { - Not Working } \\
\text { - Working }\end{array}$ & $\begin{array}{l}11 \\
220\end{array}$ & $\begin{array}{l}4.8 \\
95.2\end{array}$ & $\begin{array}{l}0 \\
29\end{array}$ & $\begin{array}{l}0 \\
100\end{array}$ & 1.4 & 0.23 \\
\hline $\begin{array}{l}\text { Mother education } \\
\begin{array}{l}\text { - Illiterate\& read /write } \\
\text { - Basic } \\
\text { - Secondary } \\
\text { - Above Secondary }\end{array}\end{array}$ & $\begin{array}{l}43 \\
34 \\
132 \\
22\end{array}$ & $\begin{array}{l}18.6 \\
14.7 \\
57.1 \\
9.5\end{array}$ & $\begin{array}{l}5 \\
2 \\
12 \\
10\end{array}$ & $\begin{array}{l}17.2 \\
6.9 \\
41.4 \\
34.5\end{array}$ & 15.4 & 0.002 \\
\hline $\begin{array}{l}\text { Father education } \\
\begin{aligned} \text { - Illiterate\& read /write } \\
\text { - Basic } \\
\text { - Secondary } \\
\text { - Above Secondary }\end{aligned}\end{array}$ & $\begin{array}{l}18 \\
29 \\
138 \\
46\end{array}$ & $\begin{array}{l}7.8 \\
12.6 \\
59.7 \\
19.9\end{array}$ & $\begin{array}{l}1 \\
4 \\
14 \\
10\end{array}$ & $\begin{array}{l}3.4 \\
13.8 \\
48.3 \\
34.5\end{array}$ & 3.8 & 0.282 \\
\hline $\begin{array}{l}\text { Socioeconomic status } \\
\text { - Low } \\
\text { - Middle } \\
\text { - High }\end{array}$ & $\begin{array}{l}12 \\
137 \\
82\end{array}$ & $\begin{array}{l}5.2 \\
59.3 \\
35.5\end{array}$ & $\begin{array}{l}2 \\
12 \\
15\end{array}$ & $\begin{array}{l}6.9 \\
41.4 \\
51.7\end{array}$ & 3.4 & 0.183 \\
\hline
\end{tabular}


Farahat et al: Indoor pesticide and children

Table (2): Total home pesticide use and Practice towards pesticide exposure

\begin{tabular}{|c|l|l|}
\hline Parameter & $\mathrm{N}(231)$ & $\%$ \\
\hline $\begin{array}{c}\text { Closing windows during } \\
\text { pecticide use }\end{array}$ & 186 & 71.2 \\
- Yes & 45 & 17.3 \\
\hline No & & \\
\hline Site of storage & 50 & 19.2 \\
- Sny place & 181 & 69.6 \\
\hline - Yecific & 10 & 3.9 \\
- No & 221 & 85 \\
\hline
\end{tabular}


Farahat et al: Indoor pesticide and children

Table (3): Relationship between indoor pesticide use and neurobehavior tests

\begin{tabular}{|l|l|l|l|l|}
\hline \multirow{2}{*}{$\begin{array}{l}\text { Neurobehavioral } \\
\text { tests }\end{array}$} & \multicolumn{2}{|l|}{ Indoor pesticide use } & \multirow{2}{*}{ T test } & \multirow{2}{*}{ P value } \\
\cline { 2 - 5 } & User $\boldsymbol{n}(\mathbf{2 3 1})$ & Non user $\boldsymbol{n ( 2 9 )}$ & & \\
\hline Similarity test & $10.5 \pm 3.7$ & $14.7 \pm 2.9$ & $\mathbf{5 . 8}$ & $<\mathbf{0 . 0 0 1}$ \\
\hline Trial making test & $82.1 \pm 21.2$ & $67.4 \pm 18.1$ & $\mathbf{3 . 5}$ & $<\mathbf{0 . 0 0 1}$ \\
\hline Digital symbols test & $22.8 \pm 4.04$ & $24.8 \pm 2.1$ & $\mathbf{2 . 6}$ & $\mathbf{0 . 0 0 1}$ \\
\hline Digital span test & $11.3 \pm 3$ & $14.3 \pm 3$ & $\mathbf{5 . 2}$ & $<\mathbf{0 . 0 0 1}$ \\
\hline PASAT* & $16.5 \pm 4.6$ & $19.7 \pm 3.5$ & $\mathbf{3 . 6}$ & $<\mathbf{0 . 0 0 1}$ \\
\hline
\end{tabular}

*Paired Auditory Serial Addition Test 
Farahat et al: Indoor pesticide and children

Table (4): Correlation coefficient ( $r$ ) between the number of pesticides' bottles used and neurobehavioral tests of the studied group

\begin{tabular}{|c|c|c|}
\hline \multirow{2}{*}{$\begin{array}{l}\text { Neurobehavioral } \\
\text { tests }\end{array}$} & \multicolumn{2}{|c|}{ N of bottles } \\
\hline & $\mathbf{R}$ & Pvalue \\
\hline Similarity test & -0.35 & $<0.001$ \\
\hline Trial making test & 0.28 & $<0.001$ \\
\hline Digital symbols test & -0.197 & 0.003 \\
\hline Digital span test & -0.38 & $<0.001$ \\
\hline PASAT* & -0.23 & 0.001 \\
\hline
\end{tabular}

*Paired Auditory Serial Addition Test 
Farahat et al: Indoor pesticide and children

\section{الملخص العربي}

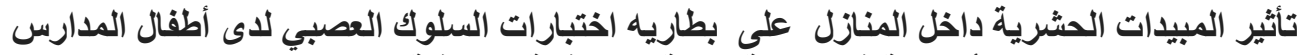

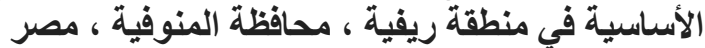

تغريد محمد فرحات ـ هاله محمد شاهين- فاطمة احمد الإسريجي ـ دينا مصطفى المطبعجي

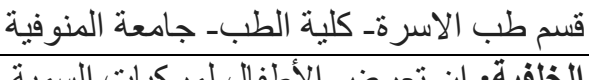

الخلفية: ان تعرض الأطفال لمركبات السمية العصبية كالمبيدات الحشرية يمثل مشكلة رئيسية لصحة الاطففال الاهداف : تهدف هذه الدراسة الي تقييم معدل استخدام المبيدات الحشريه داخل المنازل و تاثير ها على بطاريه

$$
\text { اختبار ات السلوك العصبي لدى الأطفال الذين تنز اوح أعمار هم بين 9-13 سنة. }
$$

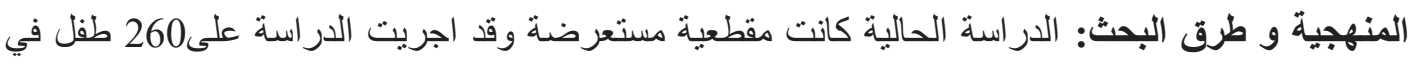
سن الدراسة (9-13سنه )من المقيدين في مدارس منشأه سلطان الابتدائية والإعدادية. خلال فترة جمع البيانات. تم تقييم جميع الأطفال من خلال أخذ التاريخ ، و الفحص العام و العصبي. تم إجر اء تقييم السلوكيات العصبية عن طريق استخدام خمس بطاريات اختبار لقياس السلوك العصبي المعرفي. النتائج: اظهرت النتائج ان ما يقرب من 89٪ من المشاركين في الدراسة يقومون باستخدام مبيدات الآفات داخل المباني. وقد وجد أن استخدام مبيدات الآفات داخل المنازل كان بدرجة كبيرة بين المشاركين الذين لم

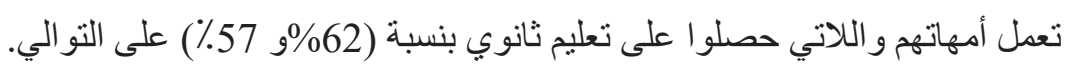

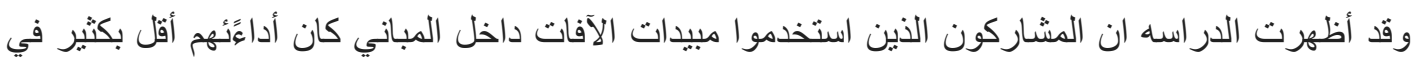
اختبارات السلوك العصبي كما كانت هناك علاقة ارتباطية موجبة بين عدد قوارير المبيدات المستخدمة واختبار السلوك العصبي توصيل الدو ائر للمجموعة المدروسة التي أجريت بينما كانت هذه العلاقة سلبية في اختبار ات السلوك العصبي اعادة الارقام والرموز الرقمية واختبار المتشابهات و اختبار الجمع.

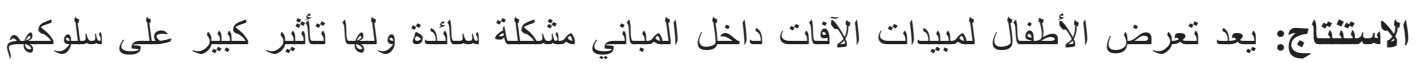
العصبي ، لذا يوصى بزيادة الوعي المجتمعي فيما يتعلق باستخدام مبيدات الآفات داخل المباني و التعرض لها. لها. الكلمات المفتاحية: مبيدات حشرية منزليه ، أطفال ، سلوك عصبي,بطاريات. 